\title{
Green Literature Ambassadors of Paganism
}

\author{
Leena B Chandnani \\ Department of Languages, Dada Ramchand Bakhru Sindhu Mahavidyalaya, \\ RTM Nagpur University, Nagpur, Maharashtra, India
}

\section{ABSTRACT}

Very well felt and expressed by the ambassadors of paganism, namely William Wordsworth, P.B. Shelly, John Keats, Alfred Lord Tennyson, Emily Dickinson, Robert Frost, Tagore, Kalidas and many other pagans that nature is full of life. For them nature was divine and an abode of peace and happiness. These pagans had experienced the spiritual power of nature. They had tasted the sip of beautiful life and the magnificent world to the fullest. Finding solace in the lap of Mother Earth, they had acquainted themselves with the existence of the universe and its sanctity manifested into divinity. The present paper is an attempt to explore the scheme that evolved in the minds of these poets who found comfort in the cradle rocked by Mother Earth. Embraced by Mother Nature they felt the power of paganism.

\section{KEY WORDS: PAGANISM HARMONIOUS DIVINITY PHILOSOPHY DISCOURSE}

\section{INTRODUCTION}

Paganism is the philosophy that teaches us to feel the presence of the divine power in all the elements of nature. History has witnessed an era where Science and Technology had started invading and conquering the globe. The two groups of people theist and atheist emerged on the worldly platform and debated about the existence of Almighty and nature. Science and technology were marching ahead blowing the trumpet of their inventions and boasting about their discoveries. The ever running globe was interrogated for its mere existence. On one hand nature with its everlasting gleaming beauty symbolised evidences to show its time abound presence and on other side science had proof to show its advancement and evolution. This battle of nature's history and science's validity had shattered the sentimental souls of poets like Jean Jacques Rousseau, William Wordsworth, John Keats, P B Shelley, Robert Frost, Alfred Tennyson and many more sentimental men of verses.

The analysis of the poetry written during Romantic period reveals mostly the love and admiration of the poets not only for reputed scientists like Newton, Franklin and

Biosc Biotech Res Comm P-ISSN: 0974-6455 E-ISSN: 2321-4007

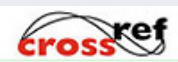

Identifiers and Pagination

Year: 2021 Vol: 14 No (8) Special Issue

Pages: $57-60$

This is an open access article under Creative DOI: $h t t p: / / d x$.doi.org/10.21786/bbrc/14.8.13
Commons License Attribn 4.0 Intl (CC-BY).
Priestley but also for the fields of knowledge such as astronomy and geometry. But it is interesting to note that in this age heart was more dominant than the head. Science exercised a positive impact on almost all the major representative poets. It was observed that while the new classical poet James Thomson explained rainbow in the Newtonian terms, the romantic poet P B Shelley used the objects of nature to explain this celestial wonder. With the storm of French Revolution all across the globe, paganism stepped into the lives of thousands of people when the pagans began to explore the wonderful wonders of nature.

Divinity, naturalism, spiritualism and meditative notes started becoming significant and their relevancy was felt by the representatives of nature. An article on Wikipedia explains, "In Philosophy naturalism is the idea of belief that only natural laws and forces operate in the universe. Adherents of naturalism assert that natural laws are the only rules that govern the structure and behaviour of the natural world and that the changing universe is at every stage of product of these laws."(www.christianity.com). The poetry of nature pagans is a step towards spreading paganism on this earth with a blend of manifestation of naturalism and embodiment in the universal sphere.

Jean Jacques Rousseau: Pioneer of Nature Poetry "Man is born free and he is everywhere in chains", the worldly famous lines are quoted by Jean Jacques Rousseau who is the pioneer pagan to initiate the movement of paganism. Jean Jacques Rousseau was born on 28 June 1712 in Geneva to a clockmaker. He was a philosopher, writer

\section{Article Information}

Received: $17^{\text {th }}$ May 2021 ccepted after revision: $29^{\text {th }}$ June 2021 
and political theorist whose writings influenced and inspired the leaders of French Revolution and romantic generation. Rousseau wanted to pursue a career as musician and composer so he moved to Paris in 1742. In Paris he was swept away with the storm of great historical watershed event of French Revolution movement. For the very first time entire Europe had tasted the sip of democracy.

This was a magnum opus historical event that influenced the global society. Rousseau's contribution to the society in this regard is valuable and no exception as he was also drifted away with this storm of revolution. His most significant contribution is his philosophy on nature and society where he argued, "that we are inherently good, but we become corrupted by the evils of society. We are born good and that is our natural state." He always said, "I prefer liberty with danger than peace with slavery" and "The world of reality has its limits; the world of imagination is boundless...."He was a pioneer who initiated the theory of Paganism with a herd of sentimental pagans who followed his path and created milestones in the history of human society.

William Wordsworth: Pietist of Paganism "Poetry is the spontaneous overflow of powerful feelings: it takes its origin from emotion recollected in tranquillity", these were the meditative notes of the renowned poet William Wordsworth who was the worshipper of nature and a poet at par excellence with profound sentiments. He felt a close bond with nature in his childhood and youth .His poems like Tintern Abbey, The Solitary Reaper, Daffodils, London, Composed upon Westminster Bridge, I wandered lonely as a cloud and many other poems have meditative tone and spiritual vehemence. He experiences the joy of dazzling nature while composing the verses. Wordsworth felt, "Nature never did betray the heart that loved her."French revolution was the period which brought anarchy and frustration among the masses. William Wordsworth tried to find solace in the company of nature.

His theory and work as a poet was influenced by the teachings of Rousseau. The powerful influence of Jean Jacques Rousseau made William Wordsworth come out with his epoch- making work, Lyrical Ballads (1978) which he composed in collaboration with another renowned poet of the time, S T Coleridge. An article in the book, A History of English Literature by Dr. T Singh expresses, "was a trumpet that heralded the dawn of a new era by making the prophecy that poetry, an unlimited and unlimitable art of expressing man's inner and deep-seated joys and sorrows, would not be fettered by the narrow and rigid bonds of artificial conventions and make-believe formalism," (flipcart.com) It is true that the composition of Lyrical Ballads lead to a revolt against the artificial passion and mechanical poetic style of the 18th century. This magnificent literary piece established the truth that if at all poetry is to remain poetry then it must express the feelings of joys, sorrows, fears, anxiety and other emotions of common men and women close to the soil and express their day to day activities of life.

The feelings of a cottage girl or the thought of a passerby during a morning walk over the hills or even an ordinary sunset felt by a village folk or listening to the song of the nightingale are some of the common feelings commonly thought and commonly felt by common man . This unsophisticated life, feelings and thoughts of simplicity of a simple villager was recognised by William Wordsworth and its blend can be felt in his poetry.

Wordsworth's paganism is always simple, rustic and believes in the dignity of man. In the background of French revolutionary fervour Wordsworth championed the cause of political and social liberty and gave way to naturalism and signified the essence of paganism when he said, "My heart leaps up when I behold a rainbow in the sky: so was it when my life began; is it now I am a man."William Wordsworth ritualized and spiritualised nature and its elements.

P B Shelley: Martyr of Paganism "0, wind, if winter comes, can spring be far behind...." Such optimistic thought provoking verses were composed by P B Shelley who is classified as a celebrated poet of nature whose work achieves the sublimity indulging in sensibility and symbolism. When Shelley started writing the French Revolution had already become a historical incident, a thing of the past with its seeds sprouting into full bloom canopy of creative literary ardour. It is observed that the spirit of the revolution breeded vigorously in his poetry. He was overtaken by harsh physical realities of life and was attracted by abstractions of subtly. All his important poems such as the Revolt of Islam, Queen Mab, Prometheus Unbound, Ozymandias and the Ode to the West Wind breathe a revolutionary spirit. His verses show the way for the emancipation of men from all kinds of shackles be it political social and even moral. Liberty and love are the two ruling parameters in Shelley's hierarchy of values and in his exaltation of them both he comes very near the Rousseauistic creed.

P B Shelley's Paganism is embedded in his utterance of solitary feelings and loneliness. Poetry and lyrics are almost invariably melancholy in their tone and have always been limiting and complaining. His paganism attains ecstatic peak when he expresses, "Oh, lift me as a wave, a leaf, a cloud! I fall upon the thorns of life! I bleed!" Shelley is the celebrated poet whose poems are the manifestation of sublimity indulged in abstractions. "Nothing in the world is single; All things by a law divine in one another's being mingle:-why not I with thine." John Keats: Celebrated Angel of Nature

A thing of beauty is a joy forever: its loveliness increases; it will never pass into nothingness.... John Keats was a great lover of nature. He loved nature not for her spiritual significance or deep message conveyed by her but for the census pleasures which she offered to the entire mankind. Keats was never bothered about the theology, humanity or metaphysics mingled with nature. He always 
wanted to know nature perfectly and to enjoy her fully with no thought of complexity. Some of his well known worldwide acclaimed poems are Ode on a Grecian Urn, Ode on Melancholy, Ode to Autumn, Ode to Nightingale, Ode to Psyche, Sleep and Poetry and La Belle Dame Sans Merci. He always felt "The poetry of Earth is never dead." Poems are rich in sensuous appeal.

They show Keats as a delicate and thorough observer of nature. While reading the best composed lines of his poetry the readers feel that Keats has built up his spiritual home in the romance draped background of middle ages and the Greece of yore which he considered to be a land of ideal beauty. Intimate contact with the harsh world of reality was unbearable to him. Though he died at an early age as he was a patient of tuberculosis, his literary contribution is abundant in the field of literature. He felt and believed, "Heard melodies are sweet, but those unheard are sweeter...."

\section{Robert Frost: Errand of Paganism}

“The woods are lovely dark and deep

But I have promises to keep

And miles to go before I sleep

And miles to go before I sleep....."

These are the popular lines of American poet, Robert Frost's poem stopping by the Woods on a Snowy Evening. Frost's nature poems and images are blend with humanity and human ties. Stopping by the Woods on a Snowy Evening, Mending Wall, Fire and Ice, The Gift, Outright, Design, Home Burial are some of the renowned poems that use nature as a metaphor and associate themselves with human flaws and spirit. His paganic attitude can be reflected in his poetry when he says, "Earth's the right place for love. I don't know where it's likely to go better."

An article on Wikipedia explains Robert Frost as a nature poet, "The influence of nature in Robert Frost's works creates a palette to paint a picture filled with symbolism for the reader to interpret. In the analysis of Robert Frost's The Road Not Taken, Tree At My Window, Two Trumps In The Mud Time and Stopping By The Woods On A Snowy Evening we can pick out specific examples to illustrate Frost's overall use of nature.

The poetry of Robert Frost has many layers of meaning. Though his poems, on the surface level, seem simple and shallow, but a deeper study reveals that Frost is a great philosopher and realist who has delved deep to know the real meaning of life. The treatment of nature in his poems is not merely related to the outward beauty of the various facets of nature, but to reveal a deeper message through it." http://devangibagohil.blogspot. com/2016/11/Robt

Alfred Tennyson: Torch Bearer of Paganism
Victorian age witnessed a shift from individualism to collectivism. Alfred Tennyson is probably the most representative literary man of the Victorian era. His poetry kept pace with the changing times and he never gave up his love for nature. He dealt with social issues of the time but never gave up the spirit of paganism which is very much reflected in his poetry like Ulysses where the protagonist Ulysses says,

\section{"The sounding furrows;for my purpose holds}

To sail beyond the sunset, and the baths

Of all the western stars, until I die

It may be the gulfs will wash us down;

It may be we shall touch the Happy Isles

And see the great Achilles....."

Nature is always dominant in his poetry characterized by reality and universal sensual appeal. An article on Wikipedia substantiates this point saying, "Alfred Lord Tennyson was a great English poet of the nineteenth century. One of the factors that lie at the root of his greatness is his treatment of nature. In almost all of his poems, long or short, nature plays a dominant role. Tennyson's treatment of nature is different from Romantic poets. He does not find any divine spirit as Wordsworth did. Unlike Shelley he does not perceive any spirit of love of nature. Nature does not offer him a refuge from the injustice of human society. His treatment of nature is characterized by realism and accuracy. He describes natural scenery as setting of his poem and as an aid to heighten a mood or feelings. We see that as a poet of nature Tennyson has distinctness. In photographic portrayal of nature he is almost unsurpassed. For delineating nature with all of it'd aspects and decorating his poetry with lovely descriptions of nature his poetry has a universal appeal."( https://www.literaturemini. com/2018/06/comment-on-tennysons-treatment-ofnature)

Kalidasa: The Messenger of Paganism Kalidasa is one of the greatest literary figures of ancient India who has many dramas and poems to his credit. He was a keen observer of nature in all its varied forms. He was endowed with an analytical mind and therefore being a poet of unparallel talent he describes the beauty of nature creating life images through his words before our eyes. To him without human beings nature is incomplete and without nature human beings are nothing. Man is an integral part of nature. Following the Indian tradition, Kalidasa in his plays and poetry stands for the harmonious relationship between man and forces of nature. Kalidas's Meghdoot (Cloud Messenger) which has been translated into many languages including English beautifully traces the close relationship between man and nature. Nature for man is not only a comforter but also a mood lifter in the moments of crisis, pain, sorrow and despair. 
Human beings have always found comfort in the lap of nature and nature too like a mother, like a friend and like a companion have shared the feelings of human beings. An article on internet says, "Kalidasa has shown the graphical descriptions of nature along with topographical details of ancient India in Maghaduta. Maghaduta depicts the deep inside of human life yet the central issue remains the natural helplessness of a passionate lover." (www. alleducationjournal.com)

Rabindranath Tagore: Cleric of Paganism Rabindranath Tagore is a renowned poet who celebrates mystic pervades of God in nature and relationship of humanity and nature. His poetic verses celebrate the fundamental humanism and the mystic quality of God and spiritual humanism. Rabindranath Tagore believes that God is not to be found in temple but among the tiller, the stone breaker, honest labour, beggar and other mystic forms. "He is there where the tiller is tilling the hard ground and where the path maker is breaking stones, He is with them in sun and in shower, and his garment is covered with dust."He also believed that God pervades in man's body, heart, mind and action. According to him God objectifies himself into the countless objects of nature like plants, trees, grass, mountains, forest, rivers, hills, valley, lakes, streams, meadows, sky and sunshine. Tagore revived the ancient classical verses and explored new dimensions of versification and personification mingled with literary power and grace.

\section{CONCLUSION}

Jean Jacques Rousseau found nature to be educative. William Wordsworth is the celebrated poet of spiritualism who finds solace in nature. PB Shelley confessed his feelings for nature with sublime subtly. For John Keats the poetry of earth is never dead and the joy of beauty is everlasting. Robert Frost associated the nature with human flaws. Alfred Tennyson's treatment of nature is realistic. Kalidas is the epitome of naturalism with his verses whisked with magnificent personified natural elements. Rabindranath Tagore discovered divinity in nature.

So ultimately these poets have found solace in the lap of Mother Nature. From time abound Mother Earth has rocked them in her cradle of comfort, glee, delight and pleasure. These ambassadors of paganism like obedient children of Mother Earth have always followed the silent instructions given by her paving way to protect the entire mankind from the clutches of the vices prevalent in human society. The marvellous verses composed by these divine pagans have created prodigy and have shown the entire human race a direction towards inwardness and universalisation. The pagans have preached that the essence of life is manifested and exhibited in the lap of Mother Nature. Nature always tries to heal man's sorrows and pains. The artificialities of human race will come to a standstill only when pagans will sermonize their ideas of paganism and worship nature. Time has come to acclaim and accolade the ambassadors of paganism who have tried to liberate the humanity from clutches of slavery of science, technology and digitalization.

\section{REFERENCES}

www.gooddreads.com>author $>799$.. www.christianity.com

flipcar.com

http://devangibagohil.blogspot.com/2016/11/Robt https://www.literaturemini.com/2018/06/comment-ontennysons-treatment-of-nature www.alleducationjournal.com 